\section{Screening Progenies of Mexican Race Avocado Genotypes for Resistance to Phytophthora cinnamomi Rands}

\author{
Enrique I. Sánchez-González, J. Guadalupe Gutiérrez-Soto, \\ Emilio Olivares-Sáenz, and Adriana Gutiérrez-Díez ${ }^{1}$ \\ Universidad Autónoma de Nuevo León, Facultad de Agronomía, General \\ Escobedo, Nuevo León, 66059 Mexico
}

\author{
Alejandro F. Barrientos-Priego \\ Universidad Autónoma Chapingo, Departamento de Fitotecnia, Chapingo, \\ Estado de Mexico, 56230 Mexico
}

\author{
Salvador Ochoa-Ascencio \\ Universidad Michoacana de San Nicolás de Hidalgo, Facultad de \\ Agrobiología Presidente Juárez, Uruapan, Michoacán, 60170 Mexico
}

Additional index words. Persea americana, var. drymifolia, genetic resistance, phytophthora root rot

\begin{abstract}
Because of the low availability of avocado rootstocks with resistance to Phytophthora cinnamomi, it is necessary to search for genotypes that offer resistance and that could be used as commercial rootstocks. The objective of this study was to select progeny from the genotypes of Mexican race avocado plants that are resistant to $P$. cinnamomi. Seedlings from 12 avocado genotypes were placed in containers inoculated with a mycelial suspension of $P$. cinnamomi. Signs of disease in the upper part of the seedlings were registered every 3 days for 8 weeks using a visual scale of damage severity. The $\chi^{2}$ test $(P<0.009)$ showed significant differences among the genotypes evaluated, with 'Todo el Año' being the most resistant, as demonstrated by its rating of $70 \%$ asymptomatic seedlings, followed by 'Plátano' with $40 \%$. The most susceptible genotypes were 'María Elena', 'Silvestre', and 'Hass', with $100 \%$ mortality. Seedling inoculation facilitated the detection of resistance to $P$. cinnamomi. 'Todo el Año' showed resistance toward $P$. cinnamomi. Therefore, individuals of its offspring could be recommended for use as rootstocks after confirming their resistance with a second evaluation, as well as performing tests in multiple localities to demonstrate their productive behavior after grafting.
\end{abstract}

The main disease affecting avocado production systems worldwide is phytophthora root rot caused by Phytophthora cinnamomi Rands (Hardham, 2005). This disease has been reported to infect avocado in $\approx 70$ countries (Pegg et al., 2002), and in Mexico it is one of the main limitations for avocado production. P. cinnamomi can affect seedlings of any age, causing root damage,

Received for publication 6 Sept. 2018. Accepted for publication 15 Mar. 2019.

This paper is part of the Master of Science thesis of E.I. Sánchez-González.

Research was conducted at the Biotechnology and Natural Sciences Laboratories of the Facultad de Agronomía, Universidad Autónoma de Nuevo León, Mexico.

We thank Consejo Nacional de Ciencia y Tecnología de Mexico, the Committee of Science and Technology in Mexico, for sponsoring E.I. Sánchez-González (scholarship no 431803) during his master studies.

${ }^{1}$ Corresponding author. E-mail: gutierrezdz@uanl. edu.mx.

This is an open access article distributed under the CC BY-NC-ND license (https://creativecommons. org/licenses/by-nc-nd/4.0/). which leads to secondary symptom development in the upper part of the plant. These symptoms include dieback of the branches, yellowing and wilted leaves, complete defoliation, and tree death, reducing the amount of production and the area cultivated (Andrade-Hoyos et al., 2015; Rodríguez, 2015). The pathogen forms resistance structures called chlamydospores that can survive for long periods in soil even without a host, making its eradication difficult once the disease has become established (Andrade-Hoyos et al., 2015). Control methods for this pathogen are chemical and biological, and the use of good cultural practices. However, they present some limitations, and the implementation of more sustainable control methods is necessary. An alternative to these methods is to use rootstocks resistant to $P$. cinnamomi, although after decades of research, few materials with a moderate level of resistance have been selected.

From the three avocado races used as rootstock, the Mexican race (Persea americana Mill. var. drymifolia) has shown more tolerance and even moderate resistance to $P$. cinnamomi (Gómez, 2014; Sánchez, 2007). Currently, different rootstocks are available in the market that are characterized as being moderately resistant to $P$. cinnamomi, including 'Barr Duke', 'Duke 6', 'Duke 7', 'Duke 9', 'Thomas', and 'Toro Canyon'-all Mexican race avocado plants (Rodríguez, 2015). The use of rootstocks from var. drymifolia is the base of 'Hass' avocado production in the principal cultivated areas in the world (Rincón-Hernández et al., 2011). As a result of factors such as an increase in plantations in areas with inadequate drainage and irrigation (Reeksting et al., 2016), as well as limited availability of resistant rootstocks and their low adaptation to different soils and climates, it is necessary to search for genotypes that present resistance to the pathogen and can be used potentially as commercial rootstocks. Some options are to use the genetic basis of $P$. americana var. drymifolia, search the existing germplasm banks in the country, and scrutinize wild materials (genotypes that are naturally present in a forest environment) for their wide genetic diversity.

Methods used to determine the resistance of $P$. americana to $P$. cinnamomi began in the 1950s with the investigations of Dr. Zentmyer and his laboratory at the University of California, Riverside, CA, with materials collected in different countries of Latin America (Zentmyer and Schieber, 1987, 1992). The resistance of avocado to $P$. cinnamomi has been determined through different methods, including the use of nutritive solutions with infective material (zoospores and mycelia), pots and germinating beds with infested soil, in vitro cultures for the inoculation of the callus, tests in infested fields, and changes in the electrical conductivity of inoculated root fragment suspensions (Salgado and Fucikovsky, 1996).

The search for genotypes resistant to $P$. cinnamomi by scrutinizing seedlings of seed or clonal origin has enabled the identification of individuals resistant to $P$. cinnamomi with potential use as clonal rootstocks (Andrade, 2012; Castañeda, 2009; Douhan et al., 2011; Ploetz et al., 2002), the identification of parents that produce high proportions of resistant progeny, and the determination of the broad-sense heritability of this trait (Ploetz et al., 2002).

Thus, the objective of our work was to evaluate progenies from 10 Mexican race avocado genotypes from the south of Nuevo Leon State, Mexico, to find resistance to $P$. cinnamomi.

\section{Materials and Methods}

Our study was conducted during Summer 2017 at the Agronomy School of Universidad Autónoma de Nuevo León in Mexico. Ten genotypes of Mexican race avocado'Todo el Año', Plátano Delgado', 'Bola', 'Leonor', 'Plátano', 'Plátano Temprano', 'Silvestre', 'María Elena', 'Criollo 3', and 'Criollo 6'-from the municipalities of Aramberri and General Zaragoza in Nuevo León, Mexico, were evaluated for their resistance to $P$. cinnamomi. The 'Hass' genotype (Mexican race $\times$ Guatemala race, from 
seed) was used as a susceptible rootstock (Ramírez et al., 2014; Rodríguez et al., 2017), whereas 'Duke 7' (Mexican race, from clonal origin) was used as a moderately resistant rootstock (Coffey, 1987). Twelve 6-month-old seedlings (from seed) for each genotype were used. Substrate and cotyledons were removed from each seedling, and the seedlings were transplanted to a $102-\mathrm{L}$ container using a mixture of vermiculite and pot soil (organic matter, 18\%; pH, 7.28) in a $1: 1$ proportion. The pot soil was sterilized by autoclaving at $121{ }^{\circ} \mathrm{C}$ and $1.05 \mathrm{~kg} \cdot \mathrm{cm}^{-2}$ for $2 \mathrm{~h}$. Twelve equidistant seedlings, one per genotype, were planted in each container.

The inoculum was a pathogenic isolate of P. cinnamomi (Sánchez-González et al., 2019) grown in $200 \mathrm{~mL} \mathrm{V8} \mathrm{Juice}{ }^{\circledR}$ clarified liquid medium (Zentmyer et al., 1976) in 10 500-mL flasks, each one inoculated with 12 cylinders (diameter, $0.5 \mathrm{~cm}$ ) with mycelia taken from the periphery of a growing oomycete colony of $P$. cinnamomi on an acidified potato dextrose agar (PDA; $39 \mathrm{~g} \cdot \mathrm{L}^{-1}$ and tartaric acid $0.14 \% \mathrm{w} / \mathrm{v}$ ) plate. Flasks were incubated at $25^{\circ} \mathrm{C}$ on a rotary shaker at 200 rpm for $13 \mathrm{~d}$ in the dark. After incubation, the contents of the flasks were homogenized and each seedling was inoculated by injecting $10 \mathrm{~mL}$ of a mycelial suspension at 128 $\mathrm{mg} \cdot \mathrm{mL}^{-1}$ (milligrams of mycelia per milliliter of medium) in the substrate, $3 \mathrm{~cm}$ from the stem, at a depth of $10 \mathrm{~cm}$. At $48 \mathrm{~h}$ after the inoculation, the seedlings were subjected to flooded conditions for a period of $48 \mathrm{~h}$ to favor the infective process of $P$. cinnamomi, and the excess water was later drained. The plants were watered with well water, maintaining the moisture of the substrate to favor $P$. cinnamomi infection and the appearance of symptoms. Laboratory conditions were a 12 -h natural light regimen, $26 \pm 2{ }^{\circ} \mathrm{C}$ room temperature, and relative humidity ranging from $80 \%$ to $90 \%$.

Three weeks after inoculation, the damage response in the aerial part of the seedlings was evaluated and registered every $3 \mathrm{~d}$ for 8 weeks based on an arbitrary visual scale of damage severity (Fig. 1). At the end of week 4 of evaluation, the seedlings were subjected to flooded conditions for $48 \mathrm{~h}$ for a second time to reactivate $P$. cinnamomi and ensure that the surviving seedlings were resistant.

The presence of the pathogen in the roots was verified at the end of the experiment by reisolation and molecular detection from root fragments of six symptomatic, six asymptomatic, and six uninoculated seedlings. Four random root fragments, $1 \mathrm{~cm}$ long, were cut from each seedling and rinsed with tap water until every particle of the substrate was removed. Later, the fragments were rinsed three times with sterile distilled water, and excess water was removed with sterile absorbent paper. The root fragments were placed in petri dishes containing acidified PDA medium supplemented with an antibiotic and a fungicide (PDA $39 \mathrm{~g} \cdot \mathrm{L}^{-1}$, tartaric acid $0.14 \% \mathrm{w} / \mathrm{v}$, amoxicillin $100 \mu \mathrm{g} \cdot \mathrm{mL}^{-1}$, and benomyl $10 \mu \mathrm{g} \cdot \mathrm{mL}^{-1}$ ), and incubated at $25{ }^{\circ} \mathrm{C}$ for 1 week. The presence of $P$. cinnamomi was confirmed by microscopy based on the mycelial morphology
(Zentmyer, 1980). Molecular detection of the pathogen was done via polymerase chain reaction (PCR) using the protocol and specific primers (LPV3) designed by Kong et al. (2003). Total DNA was extracted from the roots using the extraction buffer described by Cheng et al. (1997), and the CTAB concentration was increased to $650 \mu \mathrm{M}$. For DNA precipitation and the washing steps, washing buffer solutions 1 and 2 described by Hoisington et al. (1994) were used. Fragment amplification was confirmed by electrophoresis on $2.0 \%$ agarose gels. PCR products were purified using a Wizard ${ }^{\circledR}$ SV Gel and PCR Clean-Up System commercial kit (Promega, Madison, WI), and submitted for sequencing using the LPV3 forward primer (Eurofins Genomics, Louisville, KY).

The sequences obtained were edited using Chromas Lite v2.6.1, and the similarity among sequences was determined by alignment with the GENtle v1.9.4 software. The identity of the isolate recovered was confirmed by a sequence comparison of seven PCR products against the nucleotides database from the National Center of Biotechnology Information (NCBI).

A complete randomized block was used as an experimental design, with 10 replicates per treatment. Each genotype was considered a treatment and the experimental unit was each genotype seedling. The blocking criterion was the number of nodes per seedling. The data obtained from aerial damage severity were used to calculate the area under the disease progress curve (AUDPC) (Rodríguez et al., 2017). The relative AUDPC (rAUDPC) was calculated using the following formula: $r A U D P C=[$ AUDPC $/(D \times 100)]$, where AUDPC is the area under the disease progress curve for a genotype and $\mathrm{D}$ is the total number of days between the first and last record. A susceptibility scale was constructed for the genotypes evaluated from rAUDPC values using the following formula: $\mathrm{Sx}=[\mathrm{Sy}(\mathrm{Dx} /$ Dy)], where $S x$ is the value of the susceptibility scale calculated, Sy is the highest value of the susceptibility scale assigned, Dx is the record of the disease (rAUDPC) observed for the genotype in question, and Dy is the record of the disease (rAUDPC) observed for the genotype used as the highest susceptible control. The genotypes were classified using the following scale values: 0 to 1.5 , resistant; 1.6 to 3.0 , moderately resistant; 3.1 to 4.5 , susceptible; and 4.6 to 5 , very susceptible. Data normality and homoscedasticity were analyzed $(P<0.05)$ using the Kolmogorov-Smirnov and Levene criteria, respectively. The values of dead seedlings and asymptomatic seedlings among genotypes were compared with the $\chi^{2}$ test (Andrade-Hoyos et al., 2015). Statistical analyses were conducted using the Statistical Package for the Social Sciences (SPSS ${ }^{\circledR}$, v19).

\section{Results and Discussion}

The symptoms showed by the seedlings 3 weeks after inoculation were generally wilted leaves and the appearance of necrosis in the apical region followed by dieback that led to seedling wilting and defoliation, which agrees with previous reports (Dann et al., 2013). The seedlings that were not inoculated did not show visible symptoms related to the disease during the experiment. During the first 8 weeks of evaluation, the genotypes that showed the highest average values in the visual scale of severity were 'Criollo 3', with a value of 3.5 ; 'Hass', with a value of 3.43 ; and 'Criollo 6', with a value of 3.4, demonstrating their susceptibility to $P$. cinnamomi. 'Todo el Año' showed a value of 0.8 whereas 'Plátano Delgado' showed a value of 1 , suggesting possible resistance to the pathogen. After the ninth week, all the genotypes presented a remarkable increase in the values of the visual scale of severity. At the end of the experiment, 'Todo el Año' showed the lowest average value of 1.5, 'Criollo 3' and 'Duke 7' showed a value of 4.5 , and 'Silvestre' and 'María Elena' showed the highest values of 4.9 and 4.7 , respectively.

The genotype classification based on the susceptibility scale obtained from the values of AUDPC and rAUDPC for each genotype showed that 'Todo el Año' was the only type that was classified as resistant, with a value of 1.1 (Table 1). This genotype is differentiated from the rest by producing flowers twice a year, which allows the tree to have ripe fruit during the regular season (July-August) and when the rest of the genotypes have fruit that is developing (March-April) (SánchezGonzález et al., 2018). The 'Bola' and 'Plátano Delgado' genotypes were classified as moderately resistant, presenting values of 2.9 and 2.2, respectively. 'Hass' showed the highest AUDPC value (57.21) and was classified as very susceptible, with a value of 5.0 on the susceptibility scale, coinciding with the results found by Rodríguez et al. (2017) in their study, in which it presented quick disease development. In another study carried out by Ramírez et al. (2014), this genotype was classified as susceptible to the pathogen in some regions of Colombia. On the other hand, 'Duke 7', which is moderately resistant (Coffey, 1987), presented the second highest AUDPC value (52.65) and was classified as very susceptible with a value of 4.6 , which led Zentmyer and Schieber (1987) to conclude that this genotype can be affected by $P$. cinnamomi under severe infection conditions. Nevertheless, in a study of rootstock selection published by Andrade (2012), a mortality rate of $75 \%$ for the 'Duke 7' genotype was reported.

Eleven weeks after inoculation, 27 of 117 seedlings were asymptomatic and considered to be resistant to $P$. cinnamomi. From the asymptomatic seedlings, $26 \%$ were from the 'Todo el Año' genotype, 15\% from 'Plátano', and $11 \%$ belonged to each of the following genotypes - 'Plátano Delgado', 'Plátano Temprano', 'Leonor', and 'Bola'-whereas $7 \%$ corresponded to 'Criollo 6' and a final $4 \%$ to 'Criollo 3' and 'Duke 7'.

The $\chi^{2}$ test $(P \leq 0.009)$ showed significative differences among the genotypes evaluated (Table 2). 'Todo el Año' appeared to be 
the most resistant, presenting $70 \%$ of the asymptomatic seedlings, followed by the 'Plátano' genotype with 40\%. 'María Elena', 'Silvestre', and 'Hass' were the most susceptible, with $100 \%$ mortality. The high percentage of offspring resistant to $P$. cinnamomi from 'Todo el Año' is likely a result of the recombination of favorable alleles for this trait that originated from the female parent,

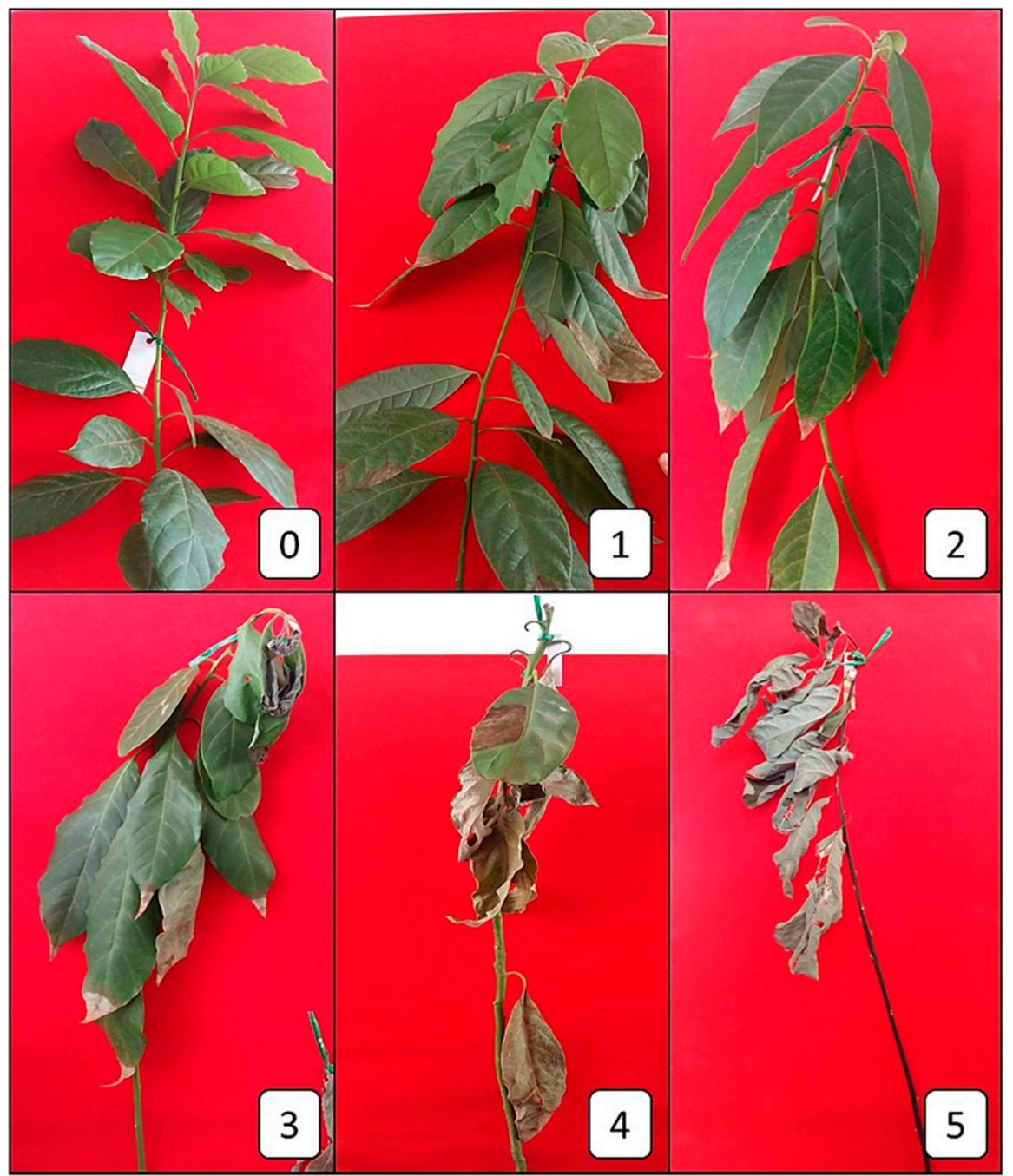

Fig. 1. Values of the arbitrary visual scale of damage severity. 0 , healthy seedling; 1 , slightly damaged (seedlings with leaves slightly wilted); 2 , moderately damaged (seedlings with moderately withered leaves); 3, damaged (seedlings with severely withered leaves and start of apical death); 4, highly damaged (seedlings with $90 \%$ to $100 \%$ death of foliar area, green stem); 5, dead seedling. considering that in the orchard, there is a single tree from this genotype and it presents a low outcrossing rate $(\approx 10 \%)$, according to a subsequent analysis with simple sequence repeat markers (unpublished data). It has been assumed that Persea americana demonstrates outcross pollination as a result of its floral dichogamy. However, different studies have shown that a high rate of self-pollination in avocado may be possible (Borrone et al., 2008; Garner et al., 2008; Kobayashi et al., 2000; Schnell et al., 2009). The differences in the resistance levels presented among the genotypes are a result of not only the high genetic variability found in individuals coming from the seed as a result of open pollination (Andrade-Hoyos et al., 2015), but also the level of pathogenicity presented by $P$. cinnamomi (Ochoa-Fuentes et al., 2015) and the interaction between these in an environment beneficial to disease development.

The defense mechanisms that have been reported in avocado and that could be associated with the different resistance levels include the following: the capability of root regeneration as a genetic resistance response based on survival, tylose formation on xylem vessels as a physical barrier to limit the pathogen on a specific region of the tissue, polyphenolic compounds that accumulate around the cells to provide strength to the cell wall and inhibit mycelial growth (Andrade, 2012), necrophiliac periderm formation in the cortical tissue, infected phloem isolation by whorls of cells formed by periclinal cell wall division (Phillips et al., 1987), and the constitutive production of compounds with inhibitory activity against $P$. cinnamomi (SánchezPérez et al., 2009).

The susceptibility presented by 'Duke 7', even when it is considered as a moderately resistant genotype, reveals the ability of $P$. cinnamomi to counteract and overcome the resistance presented by the genotype under conditions that favor its infective process (Andrade 2012; Zentmyer and Schieber, 1987), because the development of the infective process is much more severe in organic potting mixes than in soil (Ploetz et al., 2002). It is vital that when 'Duke 7' is used as a rootstock in commercial orchards grown under conditions that favor the growth of the pathogen for extended periods, the cultivar is supplemented with other control methods to avoid the defeat of the resistance mechanisms presented by the plant against P. cinnamomi.

At the end of our experiment, the avocado seedlings infected with $P$. cinnamomi developed typical root-rot symptoms. The differences among resistant and susceptible genotypes were evident (Fig. 2). These

Table 1. Values of the area under the disease progress curve (AUDPC), relative AUDPC (rAUDPC), and susceptibility scale for 12 avocado genotypes evaluated for resistance to Phytophthora cinnamomi.

\begin{tabular}{|c|c|c|c|c|}
\hline Genotype & AUDPC & rAUDPC & Susceptibility scale & Resistance level \\
\hline Todo el Año & 12.90 & 0.0086 & 1.1 & Resistant \\
\hline Bola & 33.15 & 0.0221 & 2.9 & Moderate resistant \\
\hline Leonor & 37.80 & 0.0252 & 3.3 & Susceptible \\
\hline Plátano Temprano & 40.60 & 0.0271 & 3.5 & Susceptible \\
\hline Silvestre & 46.80 & 0.0312 & 4.0 & Susceptible \\
\hline María Elena & 48.10 & 0.0321 & 4.2 & Susceptible \\
\hline Duke 7 & 52.65 & 0.0351 & 4.6 & Very susceptible \\
\hline Hass & 57.21 & 0.0381 & 5.0 & Very susceptible \\
\hline
\end{tabular}




\begin{tabular}{|c|c|c|c|c|c|}
\hline \multirow[b]{2}{*}{ Genotype } & \multirow[b]{2}{*}{ Inoculated seedlings } & \multicolumn{2}{|c|}{ Dead seedlings } & \multicolumn{2}{|c|}{ Asymptomatic seedlings } \\
\hline & & no. & $\%$ & no. & $\%$ \\
\hline Todo el Año & 10 & 3 & 30 & 7 & 70 \\
\hline Plátano & 10 & 6 & 60 & 4 & 40 \\
\hline Plátano Delgado & 10 & 7 & 70 & 3 & 30 \\
\hline Plátano Temprano & 10 & 7 & 70 & 3 & 30 \\
\hline Leonor & 10 & 7 & 70 & 3 & 30 \\
\hline Bola & 10 & 7 & 70 & 3 & 30 \\
\hline Criollo 6 & 10 & 8 & 80 & 2 & 20 \\
\hline Criollo 3 & 10 & 9 & 90 & 1 & 10 \\
\hline Duke 7 & 10 & 9 & 90 & 1 & 10 \\
\hline Hass & 7 & 7 & 100 & 0 & 0 \\
\hline Silvestre & 10 & 10 & 100 & 0 & 0 \\
\hline María Elena & 10 & 10 & 100 & 0 & 0 \\
\hline
\end{tabular}

$\chi^{2}=25.177, P \leq 0.009$.

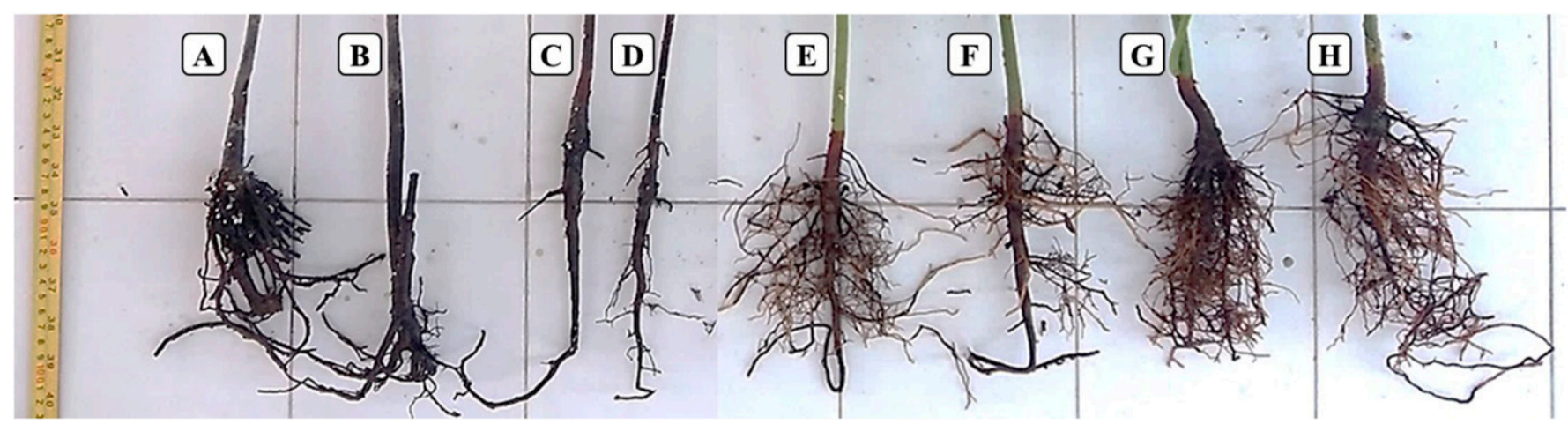

Fig. 2. Root-rot symptoms in avocado seedlings incited by P. cinnamomi. (A) 'Duke 7' resistant control. (B) 'Hass' susceptible control. (C) 'María Elena' susceptible seedlings. (D) 'Silvestre' susceptible seedlings. (E) 'Todo el Año' resistant seedlings. (F) 'Bola' resistant seedlings. (G) 'Bola' seedlings without inoculum. (H) 'Todo el Año' seedlings without inoculum.

symptoms included necrotic lesions that developed on the roots, and some of the feeder roots were black and brittle. The 'Duke 7' genotype, despite its determination as being moderately resistant, showed symptoms as severe as those of the susceptible genotypes. The seedling roots of the resistant genotypes appeared to be the healthiest when compared with susceptible ones and were similar to those of seedlings that were not inoculated.

The presence of $P$. cinnamomi on the roots of the inoculated seedlings was detected by observing a coralloid coenocytic mycelium in the root cultures under the microscope, and the obtention of amplicons of $\approx 450$ bp with the PCR protocol as described by Kong et al. (2003). During the sequence alignment with the Clustal-W algorithm, a similarity of $100 \%$ was found among the PCR products and the sequence of the positive control for $P$. cinnamomi, and the sequence comparison against the nucleotide database from NCBI showed an alignment with a region of $409 \mathrm{bp}$ from a $P$. cinnamomi sequence that encodes the storage protein LPV, with an identity of $99 \%$ and accession number AF315064.1.

Based on the results observed, we conclude that inoculation of avocado seedlings facilitates the detection of resistance to $P$. cinnamomi among genotypes. The fact that $70 \%$ of the offspring from the 'Todo el Año' genotype showed resistance to $P$. cinnamomi indicates they could be recommended for use as clonal rootstocks after confirming their resistance with a second evaluation, as well as tests in multiple edaphoclimatic conditions regarding their productive behavior when grafted.

\section{Literature Cited}

Andrade, P. 2012. Selección de portainjertos de aguacate para tolerancia-resistencia a Phytophthora cinnamomi Rands. Colegio de Postgraduados, Montecillo, México. DC thesis.

Andrade-Hoyos, P., C. De León, E. Molina Gayosso, M. de la Cruz Espíndola Barquera, D. Alvarado Rosales, and A. López Jiménez. 2015. Totipotencialidad en plántulas de aguacate en la resistencia a Phytophthora cinnamomi. Rev. Mex. Cienc. Agr. 6(2):361-373.

Borrone, J.W., C.T. Olano, D.N. Kuhn, J.S. Brown, R.J. Schnell, and H.A. Violi. 2008. Outcrossing in Florida avocados as measured using microsatellite markers. J. Amer. Soc. Hort. Sci. 133:255-261.

Castañeda, G.E.L. 2009. Búsqueda de portainjertos de aguacate tolerantes-resistente a Phytophthora cinnamomi Rands. Colegio de Postgraduados, Montecillo, México. DC thesis.

Cheng, F.S., S.K. Brown, and N.F. Weeden. 1997. A DNA extraction protocol from various tissues in woody species. HortScience 35:921-922.

Coffey, M.D. 1987. Phytophthora root rot of avocado: An integrated approach to control in California. Plant Dis. 71:1046-1052.

Dann, E.K., R.C. Ploetz, L.M. Coates, and K.G. Pegg. 2013. Foliar, fruit and soilborne diseases, p. 380-420. In: B. Schaffer, B.N Wolstenholme, and A.W. Whiley (eds.). Avocado: Botany, production and uses. CABI Publishing, Boston, MA.

Douhan, G.W., E. Fuller, B. McKee, and E. Pond. 2011. Genetic diversity analysis of avocado (Persea americana Miller) rootstocks selected under greenhouse conditions for tolerance to phytophthora root rot caused by Phytophthora cinnamomi. Euphytica 182:209-217.

Garner, L.C., V.E.T.M. Ashworth, M.T. Clegg, and C.J. Lovatt. 2008. The impact of outcrossing on yields of 'Hass' avocado. J. Amer. Soc. Hort. Sci. 133:648-652.

Gómez, J.R. 2014. Reacción a la pudrición radicular causada por Phytophthora cinnamomi Rands en dos razas y dos cultivares de palto, Persea americana Miller. Universidad Nacional Agraria La Molina, Perú. Ing. Agr. thesis.

Hardham, A.R. 2005. Phytophthora cinnamomi. Mol. Plant Pathol. 6(6):589-604.

Hoisington, D., M. Khairallah, and D. Gonzálezde-León. 1994. Laboratory protocols: CIMMYT applied molecular genetics laboratory. 2nd ed. CIMMYT, D.F., Mexico.

Kobayashi, M., J.Z. Lin, J. Davis, L. Francis, and M.T. Clegg. 2000. Quantitative analysis of avocado outcrossing and yield in California using RAPD markers. Scientia Hort. 86:135-149.

Kong, P., C.X. Hong, and P.A. Richardson. 2003. Rapid detection of Phytophthora cinnamomi using PCR with primers derived from the Lpv putative storage protein genes. Plant Pathol. 52:681-693.

Ochoa-Fuentes, Y.M., E. Cerna-Chávez, G. GallegosMorales, M. Cepeda-Siller, J. Landeros-Flores, and A. Flores-Olivas. 2015. Variabilidad patogénica 
de Phytophthora cinnamomi Rands en Persea americana Mill., de Michoacán, Mexico. Ecosist. Recur. Agropecu. 2(5):211-215.

Pegg, K.G., L.M. Coates, L. Korsten, and R.M. Harding. 2002. Foliar, fruit and soilborne diseases, p. 299-338. In: A.W. Whiley, B. Schaffer, and B.N. Wolstenholme (eds.). Avocado: Botany, production and uses. CABI Publishing, Boston, MA.

Phillips, D., B.R. Grant, and G. Weste. 1987. Histological changes in the roots of an avocado cultivar, Duke 7, infected with Phytophthora cinnamomi. Cytol. Histol. 77(5):691-698.

Ploetz, R., R.J. Schnell, and J. Haynes. 2002. Variable response of open-pollinated seedling progeny of avocado to Phytophthora root rot. Phytoparasitica 30(3):262-268.

Ramírez, J.G., D.A. Castañeda, and J.G. Morales. 2014. Estudios etiológicos de la marchitez del aguacate en Antioquia-Colombia. Rev. Ceres 61(1):50-61.

Reeksting, B.J., N.A. Olivier, and N. van den Berg. 2016. Transcriptome responses of an ungrafted Phytophthora root rot tolerant avocado (Persea americana) rootstock to flooding and Phytophthora cinnamomi. BMC Plant Biol. 16(205):1-19.

Rincón-Hernández, C.A., J. de la L. SánchezPérez, and F.J. Espinosa-García. 2011. Caracterización química foliar de los árboles de aguacate criollo (Persea americana var. drymifolia) en los bancos de germoplasma de Michoacán, México. Rev. Mex. Biodivers. 82:395-412.
Rodríguez, E. 2015. Caracterización morfológica y evaluación de la resistencia de materiales criollos de aguacate Persea americana Mill., a la pudrición radical del aguacate Phytophthora cinnamomi Rands en el centro de investigación Palmira de CORPOICA. Universidad Nacional de Colombia, Palmira, Colombia. $\mathrm{MC}$ thesis.

Rodríguez, E., A. Álvaro, A.L. Enriquez, and J.E. Muñoz-Florez. 2017. Evaluation of tolerance to Phytophthora cinnamomi Rands in avocado (Persea americana Miller.) germplasm. Acta Agron. 66(1):128-134.

Salgado, M. and L.L. Fucikovsky. 1996. Detección de materiales del género Persea spp. tolerantes a Phytophthora cinnamomi mediante conductividad eléctrica, p. 101-110. Memoria Fundación Salvador Sánchez Colin CICTAMEX S.C. Coatepec Harinas, México.

Sánchez, J. de la L. 2007. Identificación de marcadores asociados a la resistencia del aguacate raza mexicana (Persea americana Mill. var. drymifolia) al oomiceto Phytophthora cinnamomi Rands. Universidad Michoacana de San Nicolás de Hidalgo, Morelia, Michoacán. DC thesis.

Sánchez-González, E.I., A.F. Barrientos-Priego, S. Ochoa-Ascencio, J.G. Gutiérrez-Soto, E. Olivares-Sáenz, and A. Gutiérrez-Díez. 2019. Assessment of resistance to Phytophthora cinnamomi Rands in Mexican race avocado genotypes by electrical conductivity. J. Anim. Plant Sci. 39(2):6426-6434.
Sánchez-González, E.I., S. Hernández-Delgado, V.E. Aguirre-Arzola, J.A. Torres-Castillo, and A. Gutiérrez-Díez. 2018. Etiquetas de secuencias expresadas diferenciales de frutos de aguacate raza mexicana (Persea americana Mill. var. drymifolia). Rev. Bras. Frutic. 40(1): $1-9$.

Sánchez-Pérez, J. de la L., M.G. Jaimes-Lara, R. Salgado-Garciglia, and J.E. López-Meza. 2009. Root extracts from Mexican avocado (Persea americana var. drymifolia) inhibit the mycelial growth of the oomycete Phytophthora cinnamomi. Eur. J. Plant Pathol. 124:595-601.

Schnell, R.J., C.L. Tondo, J.S. Brown, D.N. Kuhn, T. Ayala-Silva, J.W. Borrone, and T.L. Davenport. 2009. Outcrossing between 'Bacon' pollinizers and adjacent 'Hass' avocado trees and the description of two new lethal mutants. HortScience 44:1522-1526.

Zentmyer, G.A. 1980. Phytophthora cinnamomi and the diseases it causes. American Phytopathological Society, St. Paul, MN.

Zentmyer, G.A., J.V. Leary, L.J. Klure, and G.L. Grantham. 1976. Variability in growth of Phytophthora cinnamomi in relation to temperature. Phytopathology 66:982-986.

Zentmyer, G.A. and E. Schieber. 1987. The search for resistance to Phytophthora root in Latin America. South African Avocado Grower's Assn. Yrbk. 10:109-110.

Zentmyer, G.A. and E. Schieber. 1992. Persea and Phytophthora in Latin America. Proc. of Second World Avocado Congress. p. 61-66. 